\title{
Improving Management of Marine Ecotourism-based on the Value of Coral Reefs Vulnerability as a Tourism Attraction
}

\author{
Nuddin Harahab ${ }^{1}$, Harsuko Riniwati ${ }^{2}$, Tiwi Nurjannati Utami ${ }^{3}$, Lina Asmarawati ${ }^{4}$ \\ \{marmunnuddin@ub.ac.id ${ }^{1}$ \} \\ Universitas Brawijaya, Indonesia ${ }^{1,2,3,4}$
}

\begin{abstract}
Ecotourism management is a relationship between tourism manager and related stakeholders. Coral reef ecotourism management is important because Coral reef is an important resource in coastal areas and has a high degree of vulnerability in the sense of being sensitive to disturbance. The purpose of this study is to analyze the status of coral reefs vulnerability as a tourist attraction. The method used is Multi-Dimensional Scaling (MDS) analysis using Rapfish (Rapid Appraisal for Fisheries) software. Assessment of the vulnerability status of coral reefs in "tiga warna" beaches used 8 dimensions: environmental conditions, fishing ports, fishing areas, Coastline and Settlement, tourism management, tourism attractions, Socio-Economic and Population, and aquaculture. The result shows from eight dimensions revealed that coral reef in tourism area was vulnerable to the existence of a fishing port, fishing area, and environmental condition. Therefore, to improve ecotourism management, these sensitive attributes (have low adaptive capacity) must be controlled, that is the distance from shipping channel, the distance from the fishing area, and coral reef cover.
\end{abstract}

Keywords: Ecotourism, Coral Reefs, Vulnerability, Beach Tourism.

\section{Introduction}

Natural resources are important assets of a country in carrying out development in the economic sector. Besides fulfilling the needs of human life, natural resources also contribute significantly to the wealth of a nation. One of the most important natural resources in coastal areas is coral reef. Coral reef ecosystem has a great function for human life in terms of ecological, social and economic function.

The ecological function of coral reef is as a life support for various types of living things around it. Coral reef can be used as a shelter, a place to look for food, and a breeding location for various marine biota. Coral reef, directly or indirectly, becomes an economic source for people as food and cosmetic ingredients. The social function of coral reef is shown by its benefits as education and research source as well as recreational facility.

Furthermore, coral reef has been degraded and constantly affected by global climate change and various human activities [1][2][3]. The high population growth rate requires a variety of 
resources to meet all needs but it lacks preservation of these natural resources. The existence of coral reef in a relatively subsistence community cause coral reef to have a high level of vulnerability or suceptible to dame. The threat is that coral reef may be extinct if there is no appropriate and wise preservation.

Malang Regency's sea area has a high potential for coral reef. However it will put the ecosystem at a high risk if the development is carried out carelessly. Tourism is an activity that has direct contact with the local communities, so that it has a social and economic impact on them. Therefore it can be said that tourism can be a catalyst for socio-economic changes in sharing the life aspects of a community. Those changes can be either positive changes or negative changes. Money-oriented tourism development and management which neglect the social and environmental aspect or conservation perspective contribute to the negative changes in tourism.

The development and management of marine tourism that do not have a conservation perspective will create vulnerability or a new threat to coral life. The level of vulnerability of coral reef is affected by several aspects such as governance, fishing and aquaculture activities, and people's activities. Therefore, the purpose of this study is to describe and analyze the vulnerability status of coral reef as a tourism area.

\section{Research Method}

\subsection{Research Location and Material}

This research was conducted on the southern coast of Malang Regency, Indonesia. The precise location was in Clungup Mangrove Conservation (CMC) along Tiga Warna beach. The study was conducted in October 2019. Quantitative analysis was employed in this study and Rapfish Analysis using Multi-Dimensional Scaling (MDS) was used to assess the status and vulnerability index of coral reef as a tourism area. Eight dimensions were set to assess the vulnerability indicators. These eight dimensions referred to several studies on coral reef. Those studies were: Building Resilience into Practical Conservation: Identifying Local Management Responses to Global Climate Change in the Southern Great Barrier Reef [4]; Prioritizing Key Resilience Indicators to Support Coral Reef Management Climate [5]; Comparison of Coral Reef Ecosystem Along a Fishing Pressure Gradient [6]; Climate Change Impacts on Coral Reefs: Synergies with Local Effects, Possibilities for Acclimation, and Management Implications [7]; Human Deforestation Outweighs Future Climate Change Impacts of Sedimentation on Coral Reefs [8]; Thirty Years of Corel Reef Change in Relations to Coast Construction and Increased Sedimentation at Pelekane Bay [9]; Spatially Explicit Assessment of Ecosystem Resilience: An Approach to Adapt to Climate Changes [10]; Herbivory and the Resilience of Caribbean Coral Reefs: Gaps Knowledge and Implications for Management [11]; Recruitment, Mortality, and Resilience Potential of Scleractinian Corals at Eilat, Red Sea [3]; Sediments and Herbivory as Sensitive Indicators of Coral Reef Degradation [12][13]. Therefore, the analysis of the vulnerability dimensions of coral reef in this research consisted of 1) environmental condition, 2) fishing port, 3) fishing area, 4) coastline and settlement area, 5) tourism management, 6) tourist attraction, 7) socio-economic and population, and 8) aquaculture. 


\subsection{Sampling and Data Collection}

The samples of this study were the people who were familiar with the research area and managers at the research location. The data were collected by conducting structured interviews and distributing questionnaires to the respondents. They had to answer and give their perceptions related to dimensions and attributes of this research.

\subsection{Data Analysis Method}

Vulnerability analysis with the RAPFISH technique was begun with reviewing attributes and defining fisheries attributes, identifying and evaluating (scoring). The next step was performing a multidimensional scaling (MDS) analysis with SPSS software to determine the ordination and stress values through ALSCAL Algorithm and performing rotation to determine the position on "bad" and "good" ordination. Next, sensitivity analysis (Leverage analysis) was performed.

Score determination for each indicator in each dimension had a logical basis for correct thinking. The score was given based on the worst and the best value qualitatively and quantitatively from indicators that reflected the perceptions of the dimensions and had clear definition in determining the score. The scoring was categorized into $1=$ low, $2=$ medium, $3=$ high. Therefore, determining the scored depended on the dimension perception analyzed. The dimensions and attributes specified in this study can be seen in Table 1 .

Table 1. Dimension, Attribute and Score of the Coral Reef Vulnerability as a Tourism Area

\begin{tabular}{|c|c|c|c|c|}
\hline No & Dimension & Attribute & Scale & Score \\
\hline \multirow[t]{4}{*}{1.} & \multirow[t]{4}{*}{$\begin{array}{l}\text { Environmental } \\
\text { Condition }\end{array}$} & $\begin{array}{l}\text { Protection forest } \\
\text { cover }\end{array}$ & $\begin{array}{l}\text { Protection forest cover }>50 \% \\
\text { Protection forest cover } 30-50 \% \\
\text { Protection forest cover }<30 \%\end{array}$ & $\begin{array}{l}1 \\
2 \\
3\end{array}$ \\
\hline & & $\begin{array}{l}\text { Mangrove forest } \\
\text { cover }\end{array}$ & $\begin{array}{l}\text { Mangrove forest cover }>50 \% \\
\text { Mangrove forest cover } 30-50 \% \\
\text { Mangrove forest cover }<30 \%\end{array}$ & $\begin{array}{l}1 \\
2 \\
3\end{array}$ \\
\hline & & Coral reef cover & $\begin{array}{l}\text { Coral reef cover }>50 \% \\
\text { Coral reef cover } 30-50 \% \\
\text { Coral reef cover }<30 \%\end{array}$ & $\begin{array}{l}1 \\
2 \\
3\end{array}$ \\
\hline & & $\begin{array}{l}\text { Distance from } \\
\text { river }\end{array}$ & $\begin{array}{l}\text { Distance from river }>3,000 \mathrm{~m} \\
\text { Distance from river } 500-3000 \mathrm{~m} \\
\text { Distance from river }<500 \mathrm{~m}\end{array}$ & $\begin{array}{l}1 \\
2 \\
3\end{array}$ \\
\hline \multirow[t]{2}{*}{2.} & \multirow[t]{2}{*}{ Fishing Port } & $\begin{array}{l}\text { Distance from } \\
\text { fishing port } \\
\text { location }\end{array}$ & $\begin{array}{l}\text { Distance from port location }>2,000 \mathrm{~m} \\
\text { Distance from port location } 500-2,000 \mathrm{~m} \\
\text { Distance from port location }<500 \mathrm{~m}\end{array}$ & $\begin{array}{l}1 \\
2 \\
3\end{array}$ \\
\hline & & $\begin{array}{l}\text { Distance from } \\
\text { fishing vessel } \\
\text { channel }\end{array}$ & $\begin{array}{l}\text { Distance from fishing vessel channel }>2,000 \mathrm{~m} \\
\text { Distance from fishing vessel channel } 500-2,000 \mathrm{~m} \\
\text { Distance from fishing vessel channel }<500\end{array}$ & $\begin{array}{l}1 \\
2 \\
3\end{array}$ \\
\hline 3. & Fishing Area & $\begin{array}{l}\text { Distance from } \\
\text { fishing area }\end{array}$ & $\begin{array}{l}\text { Distance from fishing area }>3,000 \mathrm{~m} \\
\text { Distance from fishing area } 500-3,000 \mathrm{~m} \\
\text { Distance from fishing area }<500 \mathrm{~m}\end{array}$ & $\begin{array}{l}1 \\
2 \\
3\end{array}$ \\
\hline
\end{tabular}




\begin{tabular}{|c|c|c|c|c|}
\hline & & $\begin{array}{l}\text { Percentage of } \\
\text { Fisherman } \\
\text { Catching Fish in } \\
\text { Coral Reef Area }\end{array}$ & $\begin{array}{l}\text { Percentage of fisherman }<30 \% \\
\text { Percentage of fisherman } 30-50 \% \\
\text { Percentage of fisherman }>50 \%\end{array}$ & $\begin{array}{l}1 \\
2 \\
3\end{array}$ \\
\hline \multirow[t]{3}{*}{4.} & \multirow[t]{3}{*}{$\begin{array}{l}\text { Coastline and } \\
\text { Settlement }\end{array}$} & $\begin{array}{l}\text { Coral Reef } \\
\text { Distance from } \\
\text { Road }\end{array}$ & $\begin{array}{l}\text { Coral reef distance from road }>3,000 \mathrm{~m} \\
\text { Coral reef distance from road } 500-3,000 \mathrm{~m} \\
\text { Coral reef distance from road }<500 \mathrm{~m}\end{array}$ & $\begin{array}{l}1 \\
2 \\
3\end{array}$ \\
\hline & & $\begin{array}{l}\text { Coral Reef } \\
\text { Distance from } \\
\text { Coastline } \\
\end{array}$ & $\begin{array}{l}\text { Coral reef distance from coastline }>3,000 \mathrm{~m} \\
\text { Coral reef distance from coastline } 250-3,000 \mathrm{~m} \\
\text { Coral reef distance from coastline }<250 \mathrm{~m}\end{array}$ & $\begin{array}{l}1 \\
2 \\
3\end{array}$ \\
\hline & & $\begin{array}{l}\text { Coral Reef } \\
\text { Distance from } \\
\text { Settlement }\end{array}$ & $\begin{array}{l}\text { Coral reef distance from settlement }>5,000 \mathrm{~m} \\
\text { Coral reef distance from settlement } 1000-5,000 \mathrm{~m} \\
\text { Coral reef distance from settlement }<1,000 \mathrm{~m}\end{array}$ & $\begin{array}{l}1 \\
2 \\
3\end{array}$ \\
\hline \multirow[t]{2}{*}{5.} & \multirow[t]{2}{*}{$\begin{array}{l}\text { Tourism } \\
\text { Management }\end{array}$} & $\begin{array}{l}\text { Management } \\
\text { Organization }\end{array}$ & $\begin{array}{l}\text { Complete and clear organizational structure } \\
\text { including working procedure } \\
\text { Having organizational structure but ambiguous } \\
\text { working procedure } \\
\text { Having organizational structure but no working } \\
\text { procedure }\end{array}$ & 1 \\
\hline & & $\begin{array}{l}\text { Tour Supervisor } \\
\text { and Guide } \\
\text { Service }\end{array}$ & $\begin{array}{l}\text { Standby supervisor and tour guide } \\
\text { Occasional supervisor and tour guide } \\
\text { On call supervisor and tour guide. }\end{array}$ & $\begin{array}{l}1 \\
2 \\
3\end{array}$ \\
\hline \multirow[t]{2}{*}{6.} & \multirow[t]{2}{*}{$\begin{array}{l}\text { Tourism } \\
\text { Attraction }\end{array}$} & Diving & $\begin{array}{l}\text { Limited divers according to the carrying capacity } \\
\text { Occasional divers' limitation } \\
\text { Unlimited divers. }\end{array}$ & $\begin{array}{l}1 \\
2 \\
3 \\
\end{array}$ \\
\hline & & Snorkeling & $\begin{array}{l}\text { Limited tourists according to the carrying capacity } \\
\text { Occasional tourists' limitation } \\
\text { Unlimited tourists. }\end{array}$ & $\begin{array}{l}1 \\
2 \\
3\end{array}$ \\
\hline \multirow[t]{2}{*}{7.} & \multirow[t]{2}{*}{$\begin{array}{l}\text { Socio- } \\
\text { economic and } \\
\text { Population }\end{array}$} & $\begin{array}{l}\text { Economic source } \\
\text { from fisheries } \\
\text { sector }\end{array}$ & $\begin{array}{l}\text { Income from fisheries sector }<30 \% \\
\text { Income from fisheries sector } 30-50 \% \\
\text { Income from fisheries sector }>50 \%\end{array}$ & $\begin{array}{l}1 \\
2 \\
3\end{array}$ \\
\hline & & $\begin{array}{l}\text { Economic source } \\
\text { from forestry } \\
\text { sector }\end{array}$ & $\begin{array}{l}\text { Income from forestry sector }<30 \% \\
\text { Income from forestry sector } 30-50 \% \\
\text { Income from forestry sector }>50 \%\end{array}$ & $\begin{array}{l}1 \\
2 \\
3\end{array}$ \\
\hline \multirow[t]{2}{*}{8.} & \multirow[t]{2}{*}{ Aquaculture } & $\begin{array}{l}\text { Distance from } \\
\text { fish farming } \\
\text { location to coral } \\
\text { reef area }\end{array}$ & $\begin{array}{l}\text { Distance from fish farming location to coral reef } \\
\text { area more than }>3,000 \mathrm{~m} \text {. } \\
\text { Distance from fish farming location to coral reef } \\
\text { area more than } 500-3,000 \mathrm{~m} \text {. } \\
\text { Distance from fish farming location to coral reef } \\
\text { area less than }<500 \mathrm{~m}\end{array}$ & 1 \\
\hline & & $\begin{array}{l}\text { Distance from } \\
\text { seaweed farming } \\
\text { location to coral } \\
\text { reef area }\end{array}$ & $\begin{array}{l}\text { Distance from seaweed farming location to coral } \\
\text { reef area more than }>3,000 \mathrm{~m} \text {. } \\
\text { Distance from seaweed farming location to coral } \\
\text { reef area more than } 500-3,000 \mathrm{~m} \text {. } \\
\text { Distance from seaweed farming location to coral } \\
\text { reef area less than }<500 \mathrm{~m} \text {. }\end{array}$ & 1 \\
\hline
\end{tabular}


The calculation method in determining vulnerability index categories was analyzed manually by using Microsoft Excel application program. The method of evaluating the results referred to the guideline in Table 2.

Table 2. Vulnerability Index Category

\begin{tabular}{ccc}
\hline No & Vulnerability Index & Vulnerability Level \\
\hline 1. & $0.00-33.33$ & Low \\
\hline 2. & $33.34-66.67$ & Medium \\
\hline 3. & $66.68-100.00$ & High \\
\hline
\end{tabular}

\section{Result and Discussion}

The coral reef vulnerability index as a tourism area was examined from eight dimensions namely, 1) environmental condition, 2) fishing port, 3) fishing area, 4) coastline and settlement area, 5) tourism management, 6) tourist attraction, 7) social economy and population, and 8) aquaculture.

\subsection{Environmental Condition Vulnerability Index}

There were four attributes of environmental vulnerability that were analyed in this study. The attributes consisted of protection forest cover, mangrove forest cover, coral reef cover, and distance to river. The result of the study revealed that coral reef cover had a high vulnerability index value of $23.75 \%$. Then, it was followed by protection forest cover with an index value of $11.97 \%$. The value of environmental condition vulnerability index is shown in Figure 1.

Leverage of Attributes

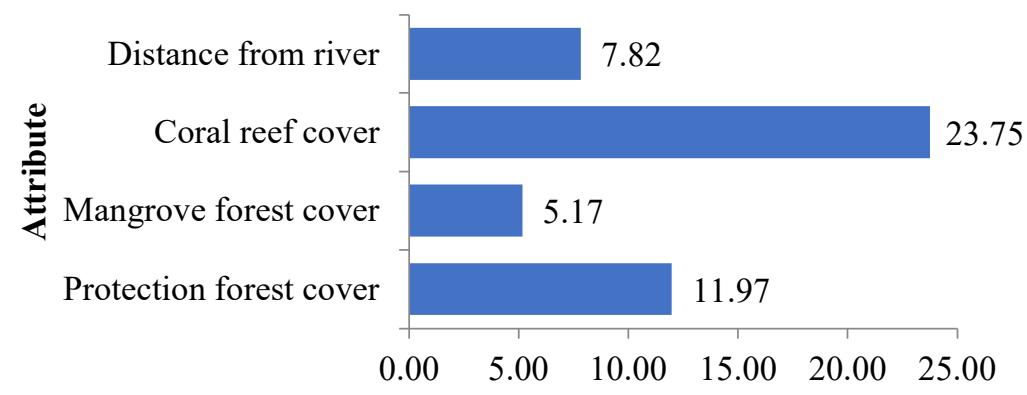

Root Mean Square Change in Ordination when Selected Attribute Removed (on Vulnerability scale 0 to 100 )

Fig. 1. Environmental Condition Vulnerability Index. 
Based on Figure 1, coral reef cover is vulnerable considering the research area is very close to hill and protection forest. If there is damage to the forest, it will definitely cause erosion and the river flow will carry a lot of sediment; this sedimentation threatens the life of coral reef as explained by [8][12]. Thus, management at the local scale of sedimentation is suggested as a relevant attempt to keep the coral reef life.

\subsection{Fishing Port Vulnerability Index}

There were two attributes of fishing port vulnerability that were analyzed in this study. The attributes consisted of distance from shipping channel and distance from port location. Among the two attributes, the distance from shipping channel indicated a high vulnerability index value of $24.01 \%$. Meanwhile the distance from the port location attribute was in the second level with an index value of $23.22 \%$. The index value is shown in Figure 2.

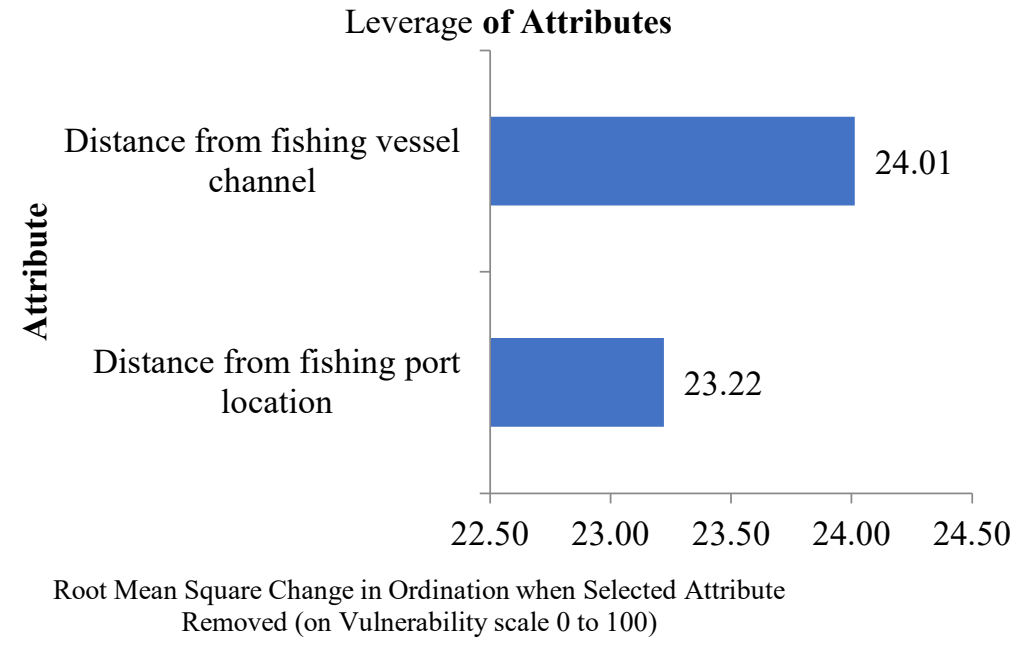

Fig. 2. Fisheries port vulnerability index.

The existence of fishing port is a threat to the coral reef surrounding the port. The threat can be in the form of physical and non-physical disturbances related to human activities near the port. In relation to coral reef existence in the future [3]; and Mellin [13] explained that the degradation trend of local coral reef caused by adverse human activities can be reduced or recovered.

\subsection{Fishing Area Vulnerability Index}

There were two attributes of fishing area vulnerability that were analyzed in this study. The attributes were the number of fishermen who catch fish and the distance from fishing location. From these two attributes, it could be concluded that the high vulnerability was the distance from 
the fishing area with the index value of $31.74 \%$. The second attribute was the number of fishermen who catch fish with an index value of $30.07 \%$. The vulnerability index value is shown in Figure 3.

\section{Leverage of Attributes}

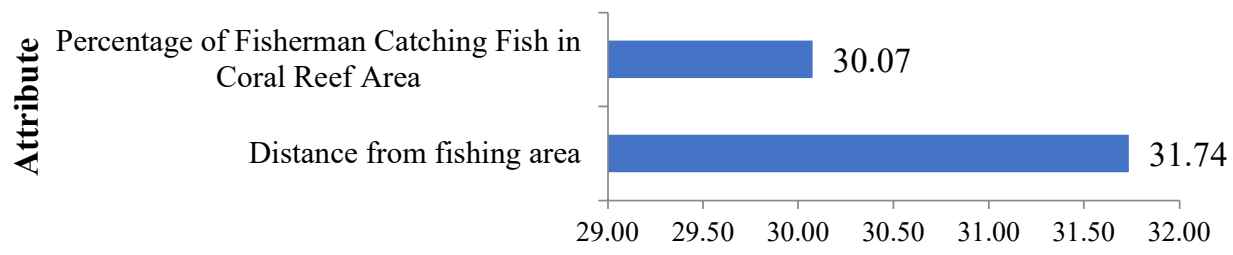

Root Mean Square Change in Ordination when Selected Attribute Removed (on

Vulnerability scale 0 to 100 )

Fig. 3. Fishing Area Vulnerability Index.

The pressure of coral reef from fishing activities is seen from the distance of coral reef to the fishing location (fishing ground). The increases in population and in market demand for fish have caused uncontrolled fishing activities affecting the fish habitat and stocks. As explained by [1][14] all forms of local pressure, overfishing and destructive fishing are kinds of threat that are commonly spread and these threats have affected more than $55 \%$ of coral reef around the world.

\subsection{Coastline and Settlement Vulnerability Index}

There were three attributes of coastline and settlement vulnerability index that were analyzed in this study. The attributes were the distance of coral reef to settlement, the distance of coral reef to coastline, and the distance of coral reef to road. Among these attributes, the distance of coral reef to coastline had a high vulnerability index value of $23.14 \%$. The second attribute was the distance of coral reef to the road with the index value of $13.64 \%$. The vulnerability index value is shown in Figure 4.

Leverage of Attributes

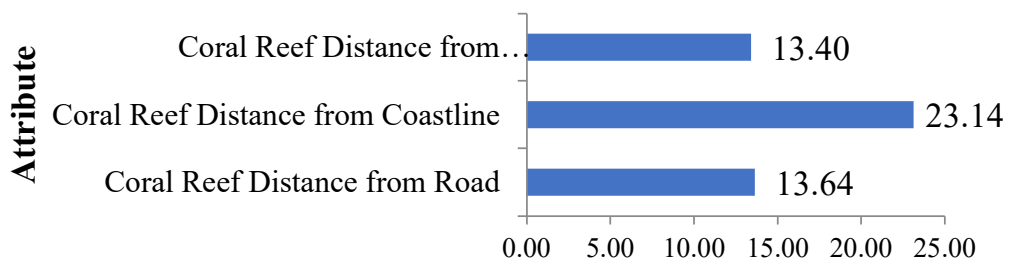

Root Mean Square Change in Ordination when Selected Attribute Removed (on Vulnerability scale 0 to 100)

Fig. 4. Coastline vulnerability index and settlement. 
The pressure of coral reef from the distance of coral reef to coastline attribute indicates that coastline give to access threatens the life of coral reef. The proximity of the reef area to coastline will possibly pose a risk of coral damage due to human activities. According to [4], it shows that the survival of coral reef is very dependent on resilience (its ability to withstand the impact of human activities and climate change).

\subsection{Tourism Management Vulnerability Index}

There were two attributes of tourism management, vulnerability that were analyzed in this study. The attributes were tour supervisor and guide service, and management organization. Among these attributes, management organization had a high vulnerability index value of $19.78 \%$. The vulnerability index value is shown in Figure 5.

Leverage of Attributes

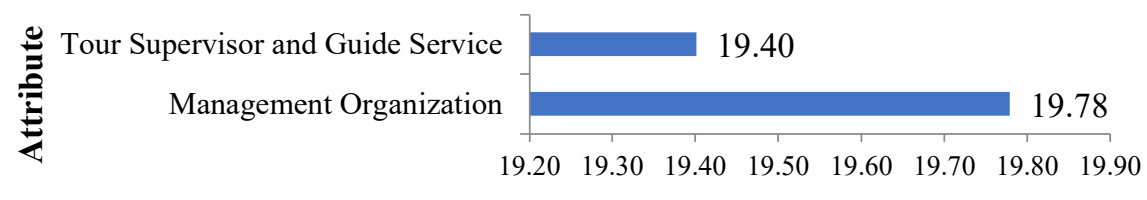

Root Mean Square Change in Ordination when Selected Attribute Removed (on Vulnerability scale 0 to 100 )

Fig. 5. Governance Vulnerability Index.

Based on Figure 5, tourism management organization is an attribute that precipitates coral reef vulnerability in tourism area. If the tourism management organization implements an appropriate ecotourism concept properly, there will be no damaged ecosystem. In principle, ecotourism management is based on conservation.

\subsection{Tourist Attraction Vulnerability Index}

There were two attributes of tourist attraction vulnerability that were analyzed in this study, snorkeling and diving. The diving attribute had a high vulnerability index value of $22.12 \%$. Then it was followed by snorkeling attribute with an index value of $21.86 \%$. The tourist attraction vulnerability index value is shown in Figure 6. 
Leverage of Attributes

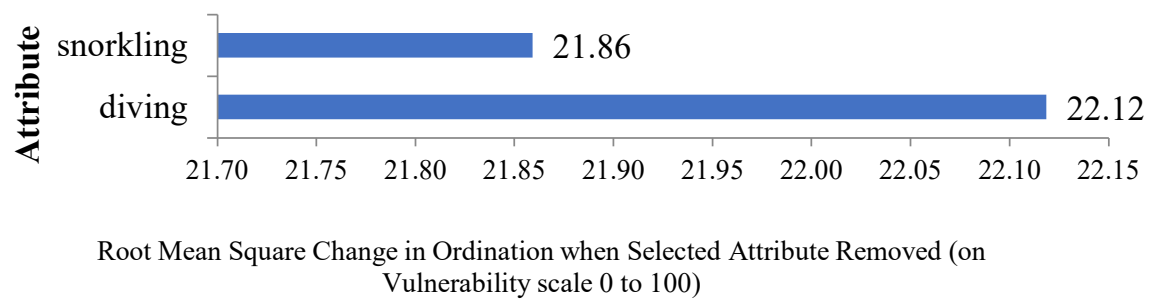

Fig.6. Tourist Attraction Vulnerability Index.

Diving attribute is the most threatening to coral reef because mostly the managers cannot control the divers' activities in the water. The divers may harm coral reef by doing irresponsible action. If the tourist activity is limited to snorkeling, it may pose smaller risk to coral reef damage. However, if the snorkeling area is too shallow, it will threat the existence of coral reef. The first threat is that the tourist will possibly stand on the coral reef. Then, the shallow water area will tend to experience temperature changing. A change of temperature will cause coral bleaching; as explained by [15][16] that generally coral reef located in shallow waters are more susceptible to bleaching than in deep waters due to its response to temperature and differences in light condition.

\subsection{Socio-Economic and Population Vulnerability Index}

There were two attributes of population and socio-economic vulnerability that were analyzed in this study. The attributes were economic source from the forestry sector and from the fisheries sector. Among these two attributes, economic source from the forestry sector had a high vulnerability index value of $22.49 \%$. The socio-economic and population vulnerability index is shown in Figure 7.

\section{Leverage of Attributes}

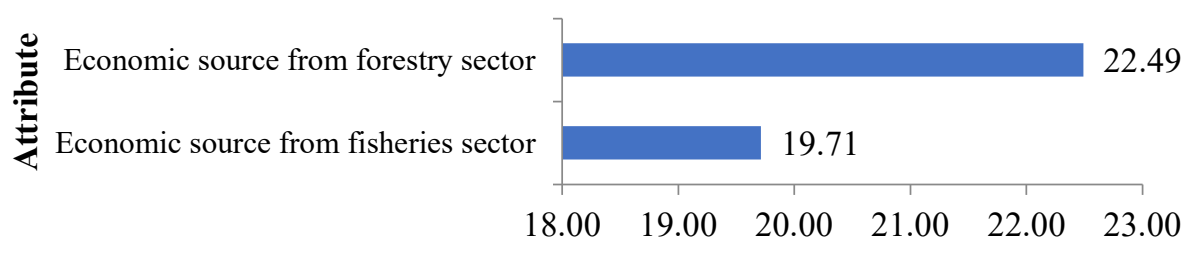

Root Mean Square Change in Ordination when Selected Attribute Removed (on Vulnerability scale 0 to 100 )

Fig. 7. Socio-Economic and Population Vulnerability Index. 


\subsection{Aquaculture Vulnerability Index}

There were two attributes of aquaculture vulnerability that were analyzed in this study. The attributes were the distance of seaweed cultivation location to coral reef location and the distance of fish farming location to coral reef location. Among these two attributes, the distance of fish farming location to coral reef location had a high vulnerability index value of $27.06 \%$. The aquaculture vulnerability index value is shown in Figure 8.

Leverage of Attributes

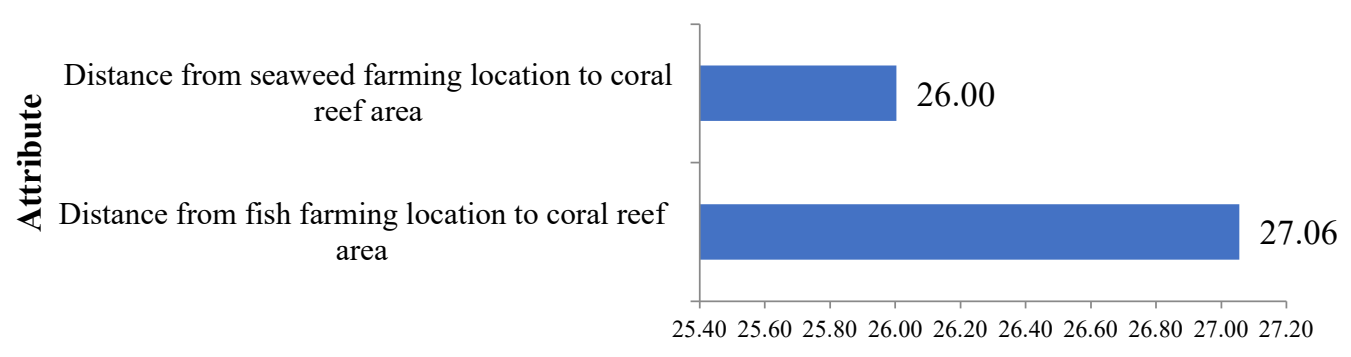

Root Mean Square Change in Ordination when Selected Attribute Removed (on Vulnerability scale 0 to 100$)$

Fig. 8. Fisheries Cultivation Vulnerability Index

Based on Figure 8, the distance of fish farming location to coral reef is the attribute that makes coral reef vulnerable. In addition, fish farming activities will have a negative impact on coral reef.

\subsection{Multi Dimension Vulnerability Index}

Based on the results of multi-dimensional analysis, the highest vulnerability index was the fishing port dimension with a value of $60.13 \%$ (medium category). Then it was followed by the fishing area dimension with a value of $54.61 \%$ (medium category), and environmental condition dimension with an index value of $53.33 \%$ (medium category). The vulnerability index of coral reef as a tourism based on the eight dimensions can be seen in Figure 9.

As seen on Figure 9, the three highest vulnerability values were fishing port, fishing area, and environmental condition dimension with high vulnerability status. Even though their values in the analysis result were categorized as medium, the index values approached the high index value. These results prove that fishing port, fishing area, and environmental condition are very important dimensions to consider. Ecotourism management, in this case must be able to control these 3 dimensions that most determine vulnerability (fishing port, fishing area, and environment conditions), the laverage of attributes of each of these dimensions must be managed properly. This proves that in the implementation of conservation in coral reef ecotourism area has been well conducted. This kind of information is very necessary for ecotourism managers. The highest dimensions make coral reef vulnerable, so that kind of dimensions and attributes must be managed better. A study to find out the significant dimensions and attributes for coral reef life is important. 
That kind of study was carried out by [4][5][17][18] these researches were aimed to determine the important indicators of resilience based on expert judgment or responses.

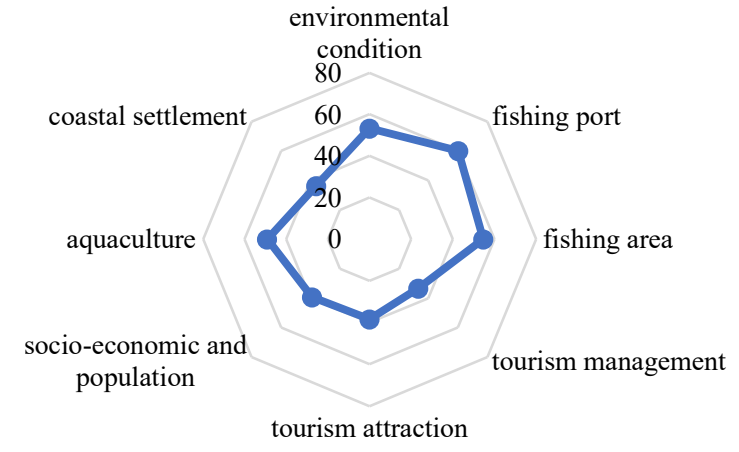

Fig. 9. Multi-dimensional Coral Reef Vulnerability Index.

\section{Conclusion}

The vulnerability analysis result of coral reef as a tourism area examined from eight dimensions revealed that coral reef in tourism area was vulnerable to the fishing port, fishing area, and environmental condition. Therefore, to improve ecotourism management, these sensitive attributes (have low adaptive capacity) must be controlled, that is the distance from shipping channel, the distance from the fishing area, and coral reef cover.

\section{References}

[1] L. M. Burke, K. Reytar, M. Spalding, and A. Perry, "Reefs at risk revisited: World Resources Institute," 2017.

[2] K. R. N. Anthony, P. A. Marshall, A. Abdulla, R. Beeden, C. Bergh, R. Black, C. M. Eakin, E. T. Game, M. Gooch, and N. A. J. Graham, "Operationalizing resilience for adaptive coral reef management under global environmental change," Glob. Chang. Biol., vol. 21, no. 1, pp. 48-61, 2015.

[3] T. Shlesinger and Y. Loya, "Recruitment, mortality, and resilience potential of scleractinian corals at Eilat, Red Sea," Coral Reefs, vol. 35, no. 4, pp. 1357-1368, 2016.

[4] J. A. Maynard, P. A. Marshall, J. E. Johnson, and S. Harman, "Building resilience into practical conservation: identifying local management responses to global climate change in the southern Great Barrier Reef," Coral Reefs, vol. 29, no. 2, pp. 381-391, 2010.

[5] T. R. McClanahan, S. D. Donner, J. A. Maynard, M. A. MacNeil, N. A. J. Graham, J. Maina, A. C. Baker, M. Beger, S. J. Campbell, and E. S. Darling, "Prioritizing key resilience indicators to support 
coral reef management in a changing climate," PLoS One, vol. 7, no. 8, p. e42884, 2012.

[6] M. Weijerman, E. A. Fulton, and F. A. Parrish, "Comparison of coral reef ecosystems along a fishing pressure gradient," PLoS One, vol. 8, no. 5, 2013.

[7] M. Ateweberhan, D. A. Feary, S. Keshavmurthy, A. Chen, M. H. Schleyer, and C. R. C. Sheppard, "Climate change impacts on coral reefs: synergies with local effects, possibilities for acclimation, and management implications," Mar. Pollut. Bull., vol. 74, no. 2, pp. 526-539, 2013.

[8] J. Maina, H. De Moel, J. Zinke, J. Madin, T. McClanahan, and J. E. Vermaat, "Human deforestation outweighs future climate change impacts of sedimentation on coral reefs," Nat. Commun., vol. 4, p. 1986, 2013.

[9] Y. Stender, P. L. Jokiel, and K. S. Rodgers, "Thirty years of coral reef change in relation to coastal construction and increased sedimentation at Pelekane Bay, Hawai'‘i,” PeerJ, vol. 2, p. e300, 2014.

[10] H. Yan, J. Zhan, B. Liu, W. Huang, and Z. Li, "Spatially explicit assessment of ecosystem resilience: an approach to adapt to climate changes," Adv. Meteorol., vol. 2014, 2014.

[11] T. C. Adam, D. E. Burkepile, B. I. Ruttenberg, and M. J. Paddack, "Herbivory and the resilience of Caribbean coral reefs: knowledge gaps and implications for management," Mar. Ecol. Prog. Ser., vol. 520, pp. 1-20, 2015.

[12] C. H. R. Goatley, R. M. Bonaldo, R. J. Fox, and D. R. Bellwood, "Sediments and herbivory as sensitive indicators of coral reef degradation," Ecol. Soc., vol. 21, no. 1, 2016.

[13] C. Mellin, M. Aaron MacNeil, A. J. Cheal, M. J. Emslie, and M. Julian Caley, "Marine protected areas increase resilience among coral reef communities," Ecol. Lett., vol. 19, no. 6, pp. 629-637, 2016.

[14] J. E. Cinner, C. Huchery, E. S. Darling, A. T. Humphries, N. A. J. Graham, C. C. Hicks, N. Marshall, and T. R. McClanahan, "Evaluating social and ecological vulnerability of coral reef fisheries to climate change," PLoS One, vol. 8, no. 9, 2013.

[15] R. I. Prieto, H. R. Bonilla, and R. R. Rodríguez, "Effects of 1997-1998 ENSO on coral reef communities in the Gulf of California, Mexico," Geofisica Int., vol. 42, no. 3, pp. 467-471, 2003.

[16] K. . B. M. L. Furby, "Susceptibility of centra red sea coral during a major bleaching event," Coral reefs 32, 2016.

[17] D. Obura and G. Grimsditch, Resilience assessment of coral reefs: assessment protocol for coral reefs, focusing on coral bleaching and thermal stress. Citeseer, 2009.

[18] H. Riniwati, N. Harahab, and Z. Abidin, "A vulnerability analysis of coral reefs in coastal ecotourism areas for conservation management," Diversity, vol. 11, no. 7, p. 107, 2019. 